\title{
FAKULTET ZDRAVSTVENIH STUDIJA SVEUČILIŠTA U MOSTARU (ŠESNAEST GODINA POSTOJANJA)
}

\author{
Ljubo Šimić \\ Fakultet zdravstvenih studija Sveučilišta u Mostaru \\ Rad je prihvaćen 20.4.2016.
}

\section{OSNIVANJE I POČETAK RADA}

Nakon osnivanja Medicinskog fakulteta na Sveučilištu u Mostaru 1997. godine i Minhenske deklaracije 2000. godine, postavilo se pitanje obrazovanja medicinskih sestara i ostalih zdravstvenih radnika iz dva razloga. Prvo, Minhenskom deklaracijom predviđeno je da sestre koje rade u zdravstvu trebaju imati visokoškolsko obrazovanje i drugo, Bolonjskim procesom je predviđeno visokoškolsko obrazovanje $\mathrm{u}$ sestrinstvu koje je potrebno radi reprodukcije nastavnog kadra iz zdravstvene njege. Osim navedenog, Klinička bolnica u Mostaru u to vrijeme imala je samo 14 sestara, uglavnom starije životne dobi, koje su imale završenu Višu medicinsku školu. U Mostaru i na cijelom području Hercegovine nije bilo mogućnosti da sestre nakon srednjoškolskog obrazovanja nastave školovanje.

To su bili razlozi da Zdravstveno-socijalno vijeće Hrvatske zajednice Herceg-Bosne, početkom 2000. godine, donese preporuku o izradi projekta i nastavnih planova i programa za osnivanje Visoke zdravstvene škole. Za navedeno je bio zadužen prodekan za nastavu na Medicinskom fakultetu Sveučilišta u Mostaru prof. dr. sc. Ljubo Šimić koji je, u suradnji s nastavnicima Medicinskog fakulteta u Mostaru, Visoke zdravstvene škole u Zagrebu i Visoke zdravstvene škole u Mariboru pripremio nastavne planove i programe za studij sestrinstva.

Senat Sveučilišta usvojio je prijedlog nastavnog plana i programa, a Upravno vijeće Sveučilišta dana 18. svibnja 2000. godine donijelo je Odluku o osnivanju Visoke zdravstvene škole. Za v.d. dekana je imenovan prof. dr. sc. Ljubo Šimić. Ministarstvo za znanost, obrazovanje, kulturu i sport Hercegovačko-neretvanske županije dana 14. rujna 2000. godine je potvrdilo Odluku Upravnog vijeća. Inicijativni odbor odabrao je nastavnike za prvu godinu studija koji su sačinjavali Nastavno vijeće Visoke zdravstvene škole Za prodekana izabran je doc. dr. Žarko Šantić, a za voditeljicu studija doc. dr. Helena Škobić. Osim njih veliki doprinos daljnjem razvoju nastavnih planova i programa, u to vrijeme, dali su i prof. dr. sc. Josip Mašković - za studij radiologije, te Nadežda Zjuzin - za studij fizioterapije.

Škola je u početku dobila skroman prostor u kampusu Sveučilišta između Ekonomskog i Pravnog fakulteta, u nekadašnjem prostoru Studentske poliklinike, gdje je bio smješten dekanat, a u prvoj godini nastava se odvijala u Srednjoj medicinskoj školi. Time su se stvorili uvjeti za provođenje razredbenog postupka i prijem studenata na I godinu studija. Nastava je počela u listopadu 2000. godine na studiju za medicinske sestre, 2001. godine na studiju za fizioterapeute, a 2002. godine na studiju za radiologe. U drugoj godini Škola je preselila u novu zgradu Strojarskog fakulteta. Prostor je adaptiran za dekanat, učionice i kabinete, a knjižnica i kopirnica su ostale u starim prostorijama sve do preseljenja $\mathrm{u}$ novosagrađenu zgradu na Bijelom brijegu.

Pri izradi nastavnih planova i programa osnovni principi bili su preporuke Minhenske deklaracije (A WHO European strategy for Nursing and Midwifery education) 2000. godine da stručni studij traje 3 godine (6 semestara), da praktični rad bude zastupljen u nastavnim planovima $50 \%$ i da nastavnici moraju biti u znanstveno nastavnom zvanju. Nastojali smo da programi budu usuglašeni s programima Visokih zdravstvenih škola u Zagrebu, Sarajevu i Mariboru, tako da bi studenti po završetku školovanja u Mostaru mogli raditi u Bosni i Hercegovini, Hrvatskoj i Europskoj uniji.

Koristeći iskustvo sa Medicinskog fakulteta, a i činjenicu da su većinu predmeta držali gostujući nastavnici iz Sarajeva, Zagreba, Splita i Osijeka, od početka smo uveli nastavu u turnusima, odnosno 
blok-nastavu, koja omogućava kontinuirano učenje, brže polaganje ispita s dobrom prolaznosti studenata i na vrijeme završavanje studija.

Uz trogodišnji stručni studij medicinskih sestara 2003. godine počinje i četverogodišnji sveučilišni studij sestrinstva nakon čega je 14 studenata nastavilo magisterij na Medicinskom fakultetu. Od 2005. godine studenti na svim studijima upisuju se na preddiplomske sveučilišne studije po novom nastavnom planu i programu koji je prilagođen Bolonjskom procesu. Godine 2011. osnovan je Studij za sanitarno inženjerstvo, a 2014. godine i Studij primaljstva.

Program školovanja na preddiplomskim studijima izrađen je na osnovu slijedećih temeljnih načela:

- Bolonjski proces - 3 plus 2 plus 3 godine.

- Minhenska deklaracija/WHO-2000/ - postavljene odrednice budućeg obrazovanja medicinskih sestara.

- Cilj 18 WHO - razvoj ljudskih resursa u zdravstvu do 2010. godine.

- The European Union standards for Nursing, European Health 21-WHO (direktive 77/452 ECC the study program must contain 4600 hours).

- Zdravstvo za sve u 21. Stoljeću/WHO.

- 1 st. International conference of Delegates of Nursing studies in higher education in enlarged Europa ( 3 godine studija sestrinstva s najmanje 180 bodova. Može se izvoditi samo na Sveučilištu i osigurava diplomu (bacc. in nursing).

\section{Smjerovi preddiplomskog studija}

- Studij sestrinstva

- Studij fizioterapije

- Studij radiologije - radiološke tehnologije

- Studij primaljstva

- Studij sanitarnog inženjerstva

Visoka zdravstvena škola je 2. ožujka 2008. godine preimenovana u Fakultet zdravstvenih studija. Akademske 2008/2009 god. počinju s radom Diplomski sveučilišni studiji/magisteriji (II stupanj) i to: Kliničke zdravstvene njege, Kliničke fizioterapije i Medicinske radiologije (radiološke tehnologije).

\section{Diplomski sveučilišni studiji - magisteriji} (II stupanj).

Studenti Fakulteta zdravstvenih studija Sveučilišta u Mostaru nakon završetka preddiplomskog sveučilišnog studija mogu upisati diplomski sveučilišni studij-magisterij ili specijalistički sveučilišni studij, na kojima usvajaju dopunska znanja i vještine koje im omogućavaju uspješno obavljanje kliničkih, upravljačkih, administrativnih, savjetničkih, edukacijskih $\mathrm{i}$ istraživačkih poslova, te nastavak na doktorskom studiju.

Nastavni planovi i programi magistarskih studija izrađeni su i usvojeni na Fakultetskom vijeću, Senatu Sveučilišta i Upravnom vijeću Sveučilišta.

Prelazak s razine Bachelor na Master razinu definiran je na Helsinškoj konferenciji (ožujak 2003. godine) gdje je konstatirano slijedeće: „Upis na Master programe obično zahtijeva posjedovanje Bachelor zvanja stečenog na akademski priznatoj visokoobrazovnoj instituciji. Bachelor i Master obrazovna zvanja trebaju imati različite definirane izlazne rezultate i trebaju biti dodijeljeni na različitim razinam. " (Conference on Master-level degrees, Helsinki 14-15. ožujak 2003. god., Conclusions and Recommendations, p.5.).

Najčešće primjenjivani obrazac u Europi je 180 ECTS bodova za Bechelor, plus 120 ECTS bodova za Master zvanje. Međutim, može biti i kontinuirano obrazovanje od 300 ECTS bodova. Princip je da su obrazovanje i praksa u vrlo uskoj vezi, te jedna na drugu snažno utječu.

\section{Smjerovi diplomskog studija Smjer - Klinička zdravstvena njega}

Klinička zdravstvena njega rezervirana je, u pravilu, za akutna stanja bolesti, što zahtijeva primjenu složenih vještina od strane liječnika i medicinskih sestara, uz primjenu i vrlo sofisticirane tehnologije u jedinici intenzivnog liječenja. Nakon otpusta iz bolnice nastoji se provoditi kvalitetna kontinuirana zdravstvena njega.

$\mathrm{Na}$ magistarskom studiju obrazovanje medicinskih sestara treba biti takvo da su sposobne sudjelovati $u$ profesionalnom i multidisciplinarnom zdravstvenom timu i osposobljene za samostalno 
donošenje odluka i preuzimanje odgovornosti za donošenje tih odluka. Magistarsko obrazovanje omogućuje reprodukciju nastavnog kadra iz Zdravstvene njege. Prema Minheskoj deklaraciji nastavnici sestrinstva mogu biti:

- osobe koje imaju sveučilišnu razinu obrazovanja,

- osobe koje svoju nastavu zasnivaju na neprekidnom istraživačkom radu,

- osobe koje su kvalificirane za izvođenje nastave,

- osobe koje imaju najmanje 2 godine prakse u području u kojem rade kao nastavnici.

Godine 1993. Conrad sa suradnicima je objavio sveobuhvatni pregled poslijediplomskog obrazovanja u publikaciji pod nazivom „A Silent success: Masters Education in the United States“. Autori su zaključili kako magistarsko obrazovanje ostvaruje značajne ciljeve, uključujući razvoj viših analitičkih vještina, razvoj šireg opsega razmišljanja, razvoj naprednih sposobnosti, izricanje mišljenja i stavova, sposobnost jasnijeg provođenja teorije u praksu, te razvoj naprednih vještina unutar određene profesije.

Magistarsko obrazovanje iz područja sestrinstva je prikladna razina obrazovanja za profesionalne medicinske sestre, osobito bolničke sestre. Elementi poput upravljanja procesom skrbi, te obrazovne teorije i metode, važan su element, no primjenjivati ih mogu samo one sestre koje su stručnjaci u naprednim kliničkim vještinama i znanju.

\section{Smjer - Klinička fizioterapija}

Razvoj fizioterapijske struke u Europi i svijetu obilježava povećan opseg znanja i vještina zbog čega programi studija moraju biti prilagođeni suvremenim potrebama struke, te aktualnim potrebama suvremenog zdravstva. Zato Master zvanja trebaju biti definirana na bazi svog sadržaja, kvalitete i izlaznih rezultata koji omogućavaju pristup doktorskim studijima. Master programi normalno nose 120 ECTS bodova.

Svjetska konfederacija za fizikalnu terapiju posvetila posebnu tematsku konferenciju o poslijediplomskoj i kontinuiranoj edukaciji fizioterapeuta u Europskom regionu (World Confederation for Physical Therapy - European Region Post-basic Proffesional Physiotherapy Education in the European Region: including Continuing and Postgraduate Education, Brussels, 2000.).

Mi smo se koristili Europskim standardima u fizioterapiji European Core Standard of Physiotherapy Practice http:// www.physio-europe.org/index3.htm (2002.) i Master's Level Programmes within postqualifying physioterapy education: CSP Criteria and Expectations London: CSP (2003.).

Naši nastavni planovi i programi izrađeni su i prilagođeni nastavnim planovima i programima School of Physiotherapy and Performance Science Universitety College Dublin, Queen Margaret University College Edinburgh i Faculty of Physioterapy Wroclaw.

Program je izrađen na osnovu slijedeći temeljnih načela:

- Bolonjska deklaracija 3+2+3,

- Cilj 18 WHO- razvoj ljudskih resursa u zdravstvu do 2010. godine,

- Zdravstvo za sve u 21 stoljeću/WHO.

\section{Smjer - Medicinska radiologija - radiološka tehnologija}

Ubrzan razvoj radiološke struke u svijetu potaknut razvojem radioloških uređaja i radiološke tehnologije doveo je do potrebe za otvaranjem novih studija iz područja radiološke tehnologije. Ovu potrebu prvi su uvidjeli u SAD-u 2005. godine kada je Joint Review Committee on Education in Radiologic Technology's (JRCERT) postavio zahtjev da voditelji i predavači studija radioloških tehnologija i slikovnih metoda do 2009. godine trebaju završiti Master's degree razinu obrazovanja. Ovaj zahtjev doveo je do otvaranja nekoliko studijskih programa na visokim učilištima u SAD-u, a među prvima je prepoznao potrebu i razvio program Thomas Jefferson University u Philadelphiji. Program se temelji na shemi studija $3+2$ gdje je uvjet za upis diplomskog magistarskog studija završetak baccalaureate degree u trajanju od tri godine i najmanje jedne godine rada u području radioloških tehnologija. Studijski program Master's degree na navedenom visokom učilištu pruža edukacijiski i upravljački pravac obrazovanja. Isto tako Midwestern State University (MSU) provodi Master of Science program za radiološke 
tehnologe koji educira studente iz edukacijskog i upravljačkog pravca.

Organizacija stručnih studija u Europi iz područja radiološke tehnologije u većini zemalja temelji se na odrednicama Bolonjske deklaracije i shemi stručnih studija $3+2$.

S obzirom na gore navedena iskustva iz svijeta i Europe razvidno je da su se razvojem radioloških tehnologija i radiološke znanosti stvorili uvjeti i potreba za otvaranjem diplomskog sveučilišnog studija medicinske radiologije.

Godine 2009. završena je nova zgrada Fakulteta sa suvremenim prostorom i opremom na Bijelom brijegu koja, uz Medicinski fakultet i Sveučilišnu kliničku bolnicu, čini suvremeni biomedicinski centar u Mostaru. Osim u BiH nastavne baze imamo i u Hrvatskoj s kojima uspješno surađujemo. Za studij sestrinstva obavljali smo i dislociranu nastavu u Orašju.

Fakultet se cijelo vrijeme, sukladno svojoj strategiji, bavio i znanstveno-istraživačkim radom, te je do sada realizirano nekoliko znanstvenih međunarodnih istraživačkih projekata i organizirana tri znanstvena simpozija iz područja sestrinstva. $\mathrm{Na}$ Fakultetu je angažirano preko 50 nastavnika i oko 30 asistenata s područja Bosne i Hercegovine, Hrvatske i Slovenije.

Dekani Fakulteta zdravstvenih studija u razdoblju od osnivanja bili su:

Prof. dr. sc. Ljubo Šimić ～2000. - 2004.

Prof. dr. sc. Mladen Mimica 2004. - 2014.

Prof. dr. sc. Ivan Vasilj 2014. - do danas.
Do 2016. godine na preddiplomskom studiju diplome je steklo: na studiju sestrinstva 584 studenata, na studiju fizioterapije 261, na studiju radiološke tehnologije 218, na studiju sanitarnog inženjerstva 28 studenata.

Na sveučilišnom diplomskom studiju-magisterij (II stupanj): Klinička zdravstvena njega 18 studenata, Radiološka tehnologija 11 studenata i Klinička fizioterapija 26 studenata/ magistara struke.

Osnivanjem Fakulteta zdravstvenih studija omogućeno je:

- Školovanje zdravstvenih radnika u Mostaru na svim razinama od srednje medicinske škole, preko 5 preddiplomskih, 3 diplomska do doktorskog studija.

- Kvalitetna zdravstvena njega, fizioterapija, radiološka tehnologija i primaljstvo u bolnicama i primarnoj zdravstvenoj zaštiti koji odgovaraju suvremenim kriterijima medicinske znanosti.

Na kraju da se vratimo sestrinstvu. Prilikom osnivanja VZŠ, kako smo već naveli, na odjelima u primarnoj zdravstvenoj zaštiti bilo je samo 14 sestara sa višom medicinskom školom, a trenutno su sve glavne sestre na Klinikama i u Domovima zdravlja diplomirane medicinske sestre ili magistre sestrinstva što daje dodatnu kvalitetu zdravstvenoj zaštiti.

Dr. sc. Ljubo Šimić, prof. emeritus 


\title{
FACULTY OF HEALTH SCIENCES UNIVERSITY OF MOSTAR (SIXTEEN YEARS OF EXISTENCE)
}

\author{
Ljubo Šimić \\ Faculty of Health Sciences, University of Mostar
}

\section{FOUNDATION AND COMMENCEMENT}

After the founding of Faculty of Medicine at the University of Mostar in 1997 and the Munich Declaration in 2000 the question on education of nurses and other health workers was raised of two reasons. First, the Munich Declaration envisaged for nurses working in health care to have a degree in higher education, and second the Bologna process provided the conditions for higher education in nursing which was necessary for the reproduction of the teaching staff of healthcare. In addition, at the time the Clinical Hospital in Mostar had only 14 nurses, most of them were senior nurses ready for retirement, and all of them finished Advanced Medical School. In Mostar and on the entire territory of Bosnia and Herzegovina, nurses were unable to continue their education after the completion of secondary school.

These were the reasons that in early 2000 the Health and Social Council of the Croatian Community of Herceg-Bosna adopted a recommendation on the development of the project, Curriculums for the establishment of the School of Health Sciences. Professor Ljubo Šimić, PhD, Dean for Academic Affairs at the Faculty of Medicine was in charge of the mentioned project, who in corporation with other lecturers from the Faculty of Medicine in Mostar, the Medical College in Zagreb and Maribor prepared and assembled the Curriculum for the nursing study program.

The University Senate adopted the proposal of the curriculum, and the Governing Council of the University on May $18^{\text {th }} 2000$ issued a Decision on the establishment of the School of Health Sciences. Professor Ljubo Šimić, PhD was appointed as the Executive Dean. The Ministry of Science, Education, Culture and Sports of Herzegovina-Neretva Canton on September $14^{\text {th }} 2000$ confirmed the decision of the Governing Council. The Initiative Board selected educators for the first year of studies that made up the Teaching Council of the School, professor Žarko Šantić, PhD was elected as the Vice Dean and professor Helena Škobić, PhD as the Head of Studies. Apart from the mentioned members, others also had great contribution for the further development of the Curriculum, professor Josip Mašković, $\mathrm{PhD}$ for radiology studies, and Nadežda Zjuzin for physiotherapy studies.

At the begging, the School was given modest facilities at the former Student Clinic in the University Campus, between the Faculty of Economics and the Law School where the Deanery of the School was situated, and in the first year the lectures were held at the Secondary Medical School in Mostar. In the second year we moved into the new building of the Faculty of Mechanical Engineering. The space was adapted for the Deanery, classrooms, and offices, but the library and copy shop remained in the old premises until relocation into the new building on Bijeli Brijeg. This created conditions for the admission procedure into the first semester of studies. The lectures began in October 2000 for the nursing study program, and in 2002 for the radiology study program.

The basic principles for the Curriculum development were based on the recommendations of the Munich Declaration (A WHO European Strategy for Nursing and Midwifery education) from 2000, according to this the professional study program lasts for 3 years ( 6 semesters), practical work represents $50 \%$ of the Curriculum, and educators must have corresponding academic titles. We tried to harmonize the programs with other Schools of Heath Sciences in Zagreb, Sarajevo, and Maribor, so that 
students upon the completion of their education in Mostar could work in Bosnia and Herzegovina, Croatia and the European Union.

Based on the experience form the Faculty of Medicine, and the fact that most of the courses were taught by visiting lecturers from Sarajevo, Zagreb, Split, and Osijek, the lectures were carried out in intervals or block scheduling which enables continuous learning, better exam statistics, and completion of studies on time.

In addition to the three-year professional study program for nurses in 2003, we also started a fouryear university study program, after which 14 students continued their education for a master's degree at the Faculty of Medicine in Mostar. Since 2005, students at our Faculty enroll undergraduate university programs based on the new Curriculum, adapted for the Bologna process. In 2011 we established the study of Sanitary Engineering and in 2014 and the study of Midwifery.

The program of education at undergraduate studies was developed on the basis of the following fundamental principles:

- The Bologna Process 3 plus 2 plus 3 years.

- Munich Declaration / WHO-2000 set guidelines for future education of nurses.

- The goal of 18 WHO-development of human resources in health care since 2010.

- The European Union standards for Nursing, European Health 21-WHO (Directives 77/452 ECC the study program must contain 4600 hours).

- Health care for all in the 21st century WHO.

- 1st. International Conference of Delegation of Nursing studies in higher education in enlarged Europe ( 3 years of nursing with at least 180 points. It can be performed only at the University and provides a degree (bacc. of nursing)

\section{Undergraduate study programs:}

- Nursing

- Physiotherapy

- Radiology - Radiological Technology

- Midwifery

- Sanitary Engineering
School of Health Studies was renamed to The Faculty of Health Sciences on March $2^{\text {nd }} 2008$.

In the academic year of 2008/2009 we started with graduate/master's Degree programs: Clinical health care, Clinical Physiotherapy and Medical Radiology (radiological technology).

\section{Graduate study programs - master's Degree (sec- ond cycle)}

Students of the Faculty of Health Sciences at the University of Mostar upon the completion of undergraduate studies may enroll to graduate studies master's Degree, or to a professional university study program to acquire additional knowledge and skills that enable them to successfully conduct clinical, management, administrative, advisory, educational, and research activities and the continuation of the doctoral studies.

The Curriculums for the master's programs were developed and adopted at the Faculty Council, the Senate and the University Governing Council.

The transition from Bachelor to Master level is defined by the Helsinki Conference (March 2003), where the following is stated: "Admission to the Master program usually requires owning a Bachelor title acquired on an acclaimed higher education institution. Bachelor and Master educational titles should have differently defined outputs and should be awarded at different levels." (Conference on Master-level degrees, Helsinki 14th to 15 March 2003, Conclusions and Recommendations, p.5.)

The most common form applied in Europe is 180 ECTS credits for the Bachelor + 120 ECTS credits for the Master title. However continuous education may have 300 ECTS credits.

\section{University Graduate Programs Clinical Healthcare}

Clinical healthcare is generally reserved for acute diseases which require the implementation of complex skills from the doctor and nurses with the use of very sophisticated technology in the intensive care unit. After hospital discharge continuous implementation of high quality healthcare should continue. 
At the Masters course the education of nurses should be such that they are able to participate in a professional and multi-disciplinary health care team and are capable of independent decision making and taking responsibility for these decisions. Master's training allows the reproduction of healthcare's teaching staff. According to the Munich Declaration educators for the nursing courses can be:

- individuals who have a university level education,

- individuals that base their teaching on continuous research,

- individuals who are qualified to teach

- individuals that have at least two years of practice in the field in which they work as educators

In 1993, Conrad and his associates published a comprehensive review of post-graduate education in the publication entitled: "A Silent success: Masters Education in the United States". The authors concluded that master's education achieves significant goals, including the development of higher analytical skills, the development of a broader range of thinking, the development of advanced capabilities, the imposition of opinions and attitudes, the ability of clearer implementation of theory into practice, and the development of advanced skills within a specific profession.

Master's education from the field of nursing is the appropriate level of education for professional nurses, in particular hospital nurses. Elements such as the management of the process of care, as well as educational theories and methods, are an important element, but can only be applied by nurses who are experts in advanced clinical skills and knowledge.

\section{Clinical physiotherapy}

The development of profession of physiotherapy in Europe and the world is marked by the increased range of knowledge and skills, for which the study programs must be adapted to the new needs of the profession and the current needs of modern healthcare. Therefore Master titles should be defined on the basis of their content, quality and output results which allow access to doctoral studies. Master programs normally correspond to 120 ECTS credits.
The World Confederation for Physical Therapy dedicated a special thematic conference on graduate and continuing education of physical therapists in the European region (World Confederation for Physical Therapy - European Region Post-basic Professional Physiotherapy Education in the European Region: including Continuing and Postgraduate Education, Brussels. 2000).

We used the European standards in physiotherapy, European Core Standards of Physiotherapy Practice http: // www.physio-europe.org/index3. htm (2002) and Master, with Level Programs within post-qualifying physiotherapy education: CSP Criteria and Expectations London CSP (2003).

Our Curriculums were made and adapted according to the Curriculums of the School of Physiotherapy and Performance Science Universities College Dublin, Queen Margaret University College in Edinburgh and the Faculty of Physiotherapy Wroclaw.

The program is based on the following fundamental principles:

- The Bologna Declaration $3+2+3$

- The goal of 18 WHO-development of human resources in healthcare until 2010

- Health for all in the 21st century WHO.

\section{Medical Radiology - Radiological Technology}

The rapid development of the radiological profession in the world, prompted by the development of radiological devices and radiological technology, has led to the need to open new studies in the domain of radiological technology. This need was first seen in the US in 2005, when the Joint Review Committee on Education in Radiological Technology's (JRCERT) demanded that the leaders and lecturers of radiological technology studies and imaging methods by 2009 should have Master's degree level of education. This requirement has led to the opening of a few study programs at universities in the United States, and among the first to recognize the need and developed a program was the Thomas Jefferson University in Philadelphia. The program is based on a scheme of studies $3+2$, where the condition of admission to graduate master studies is the 
completion of baccalaureate degree in the duration of three years and at least one year of work experience in the field of radiological technology. The Master's degree program at these institutions provides education and management course education. Likewise the Midwestern State University (MSU) carries out a Master of Science program, for radiology technologists, which offers students educational and management course education.

The organization of professional studies of radiological technology in Europe, in most countries is based on the guidelines of the Bologna Declaration and a scheme of professional studies $3+2$.

Considering the above experience of the world and Europe, it is clear that the development of radiological technology and radiological science created the conditions and the need for a graduate study program of medical radiology.

In 2009 we completed the new building of the Faculty with the modern space and equipment on Bijeli Brijeg, and together with the Faculty of Medicine and The University Clinical Hospital this became a contemporary biomedical center in Mostar. In addition to the teaching bases in Bosnia and Herzegovina we have bases in Croatia with which we cooperate successfully. We also carried out dislocated courses in Orašje.

The whole time, the Faculty, in accordance with its strategy, dealt with scientific research and has so far realized several international scientific research projects and organized three scientific symposiums on nursing. The Faculty collaborates with more then 50 professor and 30 teaching assistants from Bosnia and Herzegovina, Croatia, and Slovenia.
Deans of the Faculty of Health Studies in the period from the establishment were:

$$
\begin{array}{ll}
\text { Professor Ljubo Šimić, PhD } & 2000-2004 \\
\text { Professor Mladen Mimica, PhD } & 2004-2014 \\
\text { Professor Ivan Vasilj, PhD } & 2014-\text { present. }
\end{array}
$$

Until 2016, the following number of students acquired undergraduate level diplomas: nursing - 584, physiotherapy - 261, radiological technology - 218, sanitary engineering - 28 students. At the university graduate studies-master's degree (level II): Clinical healthcare 18 students, Radiological Technology 11 students and Clinical Physiotherapy 26 students.

The establishment of the Faculty of Health Studies enabled:

- Training of health workers in Mostar at all levels from secondary medical school, to 5 undergraduate programs, 3 graduate programs, and one doctoral program.

- Quality health care, physiotherapy, radiological technology and midwifery in hospitals and primary health care that fits the criteria of modern medical science.

Finally, let us return to nursing, at the time of establishment of the School of Health Sciences, as we already stated, the departments of primary healthcare had only 14 nurses with a diploma of advanced medical school, and today most of them are head nurses at Clinics and Health Centers, or bachelors and master's of nursing which adds additional quality to healthcare.

Ljubo Šimić, Professor Emeritus 